\title{
Application of a New Cultivation Model in an Undergraduate 'Convention and Exhibition Management' Study Program
}

\author{
https://doi.org/10.3991/ijet.v14i18.11332 \\ Hui Zhang, Rongteng Zhang ${ }^{(\varpi)}$, Jie Yin \\ Huaqiao University, Quanzhou, China \\ zhimcf98@126.com
}

\begin{abstract}
Convention and exhibition management is a practical and emerging new major in colleges and universities. Students are required to master strong practical and comprehensive coordination skills. However, the professional demand of the convention and exhibition industry cannot be met under the traditional general education training model. Hence, the present study combines the professional work-oriented undergraduate training with the cooperative education concept and proposes the industry accreditation plus government advisory cooperative undergraduate training model. In addition, a schoolenterprise dual-element student training system is built. The key realization path of the "four in one" of the government, school, industry, and students with students as the core is carried out combined with path-goal theory. The cultivation model proposed in this paper is approved and recognized by both students and enterprises. The reformed cultivation model improves the overall quality of graduates and the satisfaction of employers. This model can better meet the expectations from graduates of convention and exhibition majors in modern society compared with the traditional education model.
\end{abstract}

Keywords-A\&A-COOP mode, convention and exhibition management, work-oriented undergraduate cultivation, implementation path

\section{$1 \quad$ Introduction}

The convention and exhibition industry is an important form of international service trade. With its rapid development, China's convention and exhibition industry steps into a new stage of fast development [1]. The convention and exhibition management is a practical and emerging new major in colleges and universities, and cultivating various professionals is urgent [2]. The development of the operation of the convention and exhibition industry is inseparable from the integration of multisectors, multi-industries, and multi-factors. In addition, strong practical and comprehensive coordination capabilities are required from practitioners. Professional and practical training in the industry is the focus of the demand side of the convention and exhibition major and the convention and exhibition industry. However, such training is difficult for the supply side of the convention and exhibition education. Training 
practical professionals is difficult for traditional student education concept and training mode. Hence, the rapid development of the demand for qualified professionals in the convention and exhibition industry is not met. The difference between convention and exhibition professionals is the training supply. Industry professionals use demand appears, and decoupling between supply and demand exists [3].

The main challenge for higher education institutions is the lack of schoolenterprise cooperation according to the Global Education and Employment Survey data released by the World Innovation Summit for Education in 2015. The general education model carried out by convention and exhibition education is mainly followed by the work-oriented undergraduate colleges and universities [4]. This unconnected teaching method leads to students' limited knowledge system during the learning process, in which the effect of integration and learning is difficult to achieve. The difference between professionals is training, and a shortage of regional application professionals is prominent [5]. Therefore, the proposal for the training of applied convention and exhibition students is to position them servicing in the convention and exhibition industry [6]. This method will directly solve the professional and technical problems in industrial development in the convention and exhibition industry [7]. Therefore, the important issue that educators need to study is how to implement the cultivation of practical innovation ability of applied convention and exhibition undergraduates [8]. Educators also need to study the importation, absorption, digestion, utilization, and innovation of knowledge technology [9] so that professional skills can be mastered by students and their own market competitiveness can also be improved.

\section{$2 \quad$ Literature Review}

Regarding the training of professionals in the convention and exhibition management, scholars have made an extensive research on the knowledge structure and ability of convention and exhibition students. Perry (1996) surveyed the educational needs of Australian convention and exhibition planners. He pointed out that a complete meetings, incentives, conventions and exhibitions (hereinafter "MICE") education system should include five major components, which are politics/finance, management, public relations/marketing, economics/analysis, and humanities/ethics [10]. However, the MICE education system is mainly directed at exhibition organizers. McDonald et al. (2000) believed that students of convention and exhibition majors should master humanities and social sciences including empirical research methods [11]. The final learning outcomes should be reflected in the form of participation or holding real exhibitions. However, it cannot guide specific convention and exhibitions in the practice process. Hawkins et al. (1995) found that exhibition managers should integrate management, marketing, interpersonal relationships, and the use of human resources such as employees, volunteers, and participants [12]. They advocated the development of the convention and exhibition industry by focusing only on third parties. Such development puts forward pertinent suggestions for the design of the current exhibition curriculum but ignores the need to solve the comprehensive ability cultivation of applied professionals. Zyman (1999) believed that through the 
cultivation of this major, students can integrate the basic knowledge of economics, sociology, and psychology on the basis of broad basic knowledge of management [13]. However, emphasizing only on theoretical support while neglecting the practice of communication cannot provide students with a clear understanding of the profession.

In China, many educators and researchers in convention and exhibition have also launched a series of discussions. Jin (2003) pointed out that exhibition education should be in line with the industry [14], emphasizing the need to achieve close ties and cooperation between industry and education. Ma et al. (2007) pointed out that China's MICE education needs to integrate with international standards [15]. Such standards regard professional training objectives, teaching materials, teaching methods and means, and evaluation and certification systems.

However, the optimization of applied MICE professionals' training mode is already the core of the development of MICE institutions. Most of the research still focuses on the practical teaching mode and curriculum system construction. Such system continues the general education mode of undergraduate colleges and lacks special research on the training of work-oriented professionals. Huang (2010) believed that the training of convention and exhibition professionals needs international joint training [16]. Such training needs to cultivate, assist, and support professionals in the convention and exhibition industry [17]. Wang (2010) carried out a case study on the training mode of project-driven exhibition professionals and proposed a project-driven professional training model [18]. Liu (2014) explored the integration of industry, education, and research in exhibition education [3]. This integration compensates for the shortcomings of improving students' practical experience but still needs to improve students' ability to integrate theoretical knowledge and practical experience to solve problems. The system construction of the work-oriented undergraduate exhibition professional education training system is an urgent need for the development of convention and exhibition industry and exhibition education theory. At present, China must adopt the professional training mode of convention and exhibition [19] and promote the way of exhibition education in line with national and market conditions.

The present study relies on the practical development needs of China's exhibition industry and determines the target orientation of the convention and exhibition of professional training [20]. In addition, the current study analyzes the dilemma faced by students in cultivating under the target positioning [21] and combines relevant theories to innovate professionals in the convention and exhibition industry. Furthermore, this study proposes the training path for professionals of the convention and exhibition [22] to provide recommendations and reference for their professional education. 


\section{Convention and Exhibition Industry Accreditation plus Government Advisory-COOP Mode}

\subsection{COOP cooperative education model}

In the case of successful education, the Co-operative Program proposed by the University of Waterloo has been widely used worldwide [23]. The University of Waterloo's undergraduate program lasts for 4 years and 8 months. Each academic year is divided into three semesters. Each semester is practiced for 4 months. SeptemberDecember is the fall semester, January-April is the winter semester, and May-August is the spring semester. Taking a class in school is considered a study semester, whereas working in an enterprise, a factory, the government, or other departments is considered a work semester. The University of Waterloo adopts an alternate cooperative education model in which students study and interact in business, factory or government, business, etc. [24]. The University of Waterloo Cooperative Education Program is divided into three models (see Table 1).

Table 1. Three typical University of Waterloo COOP study/work alternate mode

\begin{tabular}{|l|l|l|l|l|}
\hline \multicolumn{1}{|c|}{ Year } & \multicolumn{1}{c|}{ Semester } & \multicolumn{1}{c|}{ Mode 1 } & Mode 2 & \multicolumn{1}{c|}{ Mode 3 } \\
\hline \multirow{5}{*}{ First year } & Autumn & Study & Study & Study \\
\cline { 2 - 5 } & Spring & Study & Work & Study \\
\cline { 2 - 5 } Second year & Winter & Work & Study & Break \\
\hline \multirow{5}{*}{ Third year } & Autumn & Study & Work & Study \\
\cline { 2 - 5 } & Spring & Work & Study & Work \\
\cline { 2 - 5 } & Winter & Study & Work & Study \\
\hline \multirow{5}{*}{ Fourth year } & Autumn & Work & Study & Work \\
\cline { 2 - 5 } & Spring & Study & Work & Study \\
\cline { 2 - 5 } & Winter & Work & Study & Work \\
\hline \multirow{2}{*}{ Fifth year } & Autumn & Study & Work & Study \\
\cline { 2 - 5 } & Spring & Work & Work \\
\cline { 2 - 5 } & Winter & Study & Study & Study \\
\cline { 2 - 5 } & Autumn & Work & Study & Study \\
\hline
\end{tabular}

Through the COOP mode, a professional training program with educational characteristics has been formed. The basic principles of undergraduate curriculum setting, which combines theory, practical experience, and academic learning, have been established [25]. Furthermore, a combination of higher education and practice and a unique system combining academic curriculum and work courses is created [26]. The cooperative education program is an important platform for implementing the goal of professional training. This program enables students to alternately perform full-time work (work related to learning content) in the workplace and study on campus [27]. Such program aims to ensure that students learn in school basic and theoretical knowledge during the academic semester. Furthermore, the program aims for students to achieve comprehensive ability and the cultivation of honesty and responsibility in 
the work semester of enterprise internship [28]. Taking the Bachelor of Engineering degree in the 4-year program of the School of Environment at the University of Waterloo as an example, a minimum of 20 academic credits and a minimum of 2.0 credits are required. According to the University of Waterloo's official website data, 79\% of COOP students earned more than $\$ 50,0002$ years after graduation, exceeding the average income of graduates of Ontario by $41 \%$. For students who graduated for half a year, $96 \%$ of COOP graduates work with its counterparts, exceeding Ontario graduates by 17 percentage points. At present, many colleges and universities recognize the superiority of this system. Some colleges that perceive the pulse of education and explore the pattern of education take the lead in implementing a cooperative education system. For example, Suzhou University of China introduces the training system of the University of Waterloo, sets up training centers, and strengthens the cooperation between the government and enterprises. In addition, such university has created students' paid internship and pre-employment of junior colleges, thereby forming a pyramid of school internship, pre-employment training, and practical ability cultivation.

\subsection{Convention and exhibition work-oriented undergraduate accreditation plus government advisory-COOP mode}

The core of improving students' practical ability is that the training process must respond flexibly to social needs, focus on the cultivation of students' practical ability, and achieve close integration with the industry [29]. The process of training workoriented undergraduate professionals focuses on strengthening the participation of selected enterprises through the platform established by the industry and the government. A school-enterprise exchange from theory to practice professional training model is formed through the cooperative education of work-study program [30]. On the one hand, an industry accreditation platform is established through the introduction of the industry certification system of cooperative education projects. Furthermore, standards and procedures for cooperative education project certification are formulated, thereby promoting the communication of cooperative education stakeholders and incorporating the main demand system of the industry. On the other hand, through the Education Bureau and the Convention and Exhibition Bureau establishing an advisory platform, scholarships for COOP students are set up. Furthermore, COOP project advisory committee and COOP administrative agency are established, thereby providing funding support and policy support for COOP projects. At the same time, the school-enterprise dual-element practice teaching system supported by industry Accreditation plus government Advisory (hereinafter "A\&A") is proposed. Moreover, a professional application-oriented undergraduate professional training A\&A-COOP is formed and shown in Figure 1. The school teaching team and international work teams will alternately train students who study in formal courses and work practices in the form of project teams. Such training can be done with the filtering of the industry system certification platform and the support of the government consultant platform. 
Internship work must be related to the convention and exhibition industry. Most job positions for students are selected and developed by the school. Students must apply for a business interview, and students and the company create a two-way employee-employer selection. Students will work in an enterprise after the two parties are satisfied. Students can also find jobs on their own, but the positions need to be recognized by the school. In addition to differences in wages and insurance, students' work is the same as that of long-term employees. The school does not participate in employers' management of students and does not take legal responsibility for students' behavior at work. Employers have no legal commitment to the school, and students are formally required by employees but also take student backgrounds into account. Working and studying in enterprises is a course for students who participate in industry-university cooperative education. Students can obtain credit for participating in the cooperative education between industry and education only after passing the assessment. At the end of each semester, students are required to complete a report to take credits reviewed by the school or tutors. An undergraduate who has completed a cooperative education gains almost 2 years of work experience. Most of those experiences are obtained in four to six different positions in four semesters [31].

The A\&A-COOP Education Council is mainly responsible for planning the overall development direction and opportunities. Furthermore, such a council is responsible for deliberating and devising new educational projects, overall direction, and recommendations related to the curriculum. The curriculum includes the COOP education leaders of the chairman, secretary, industry, government, institutions, enterprises, and a student representative. The Education and Career Action (ECA) is responsible for the day-to-day operations of the A\&A-COOP system and a series of services related to the career which has a department with the local and overseas business unit. ECA communicates with local employers and international employers and provides market development, employment relationships, and vocational guidance for students to improve the efficiency of the employment process. The main functions of the A\&ACOOP Student Council are to collect feedback and suggestions from students and provide decision-making assistance. Student managers participating in the A\&ACOOP teaching model system have more opportunities to become future leaders in the exhibition industry [32].

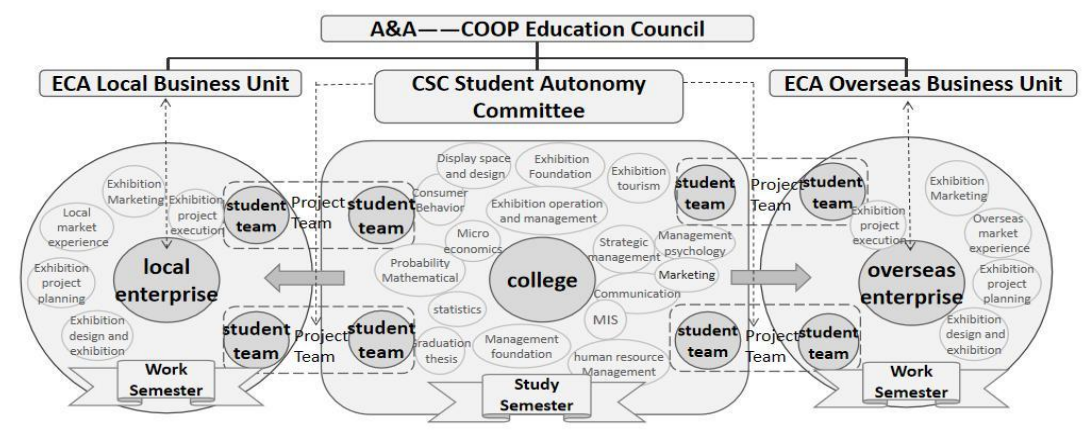

Fig. 1. Operation mechanism of MICE work-oriented undergraduate A\&A-COOP mode 


\section{Cultivation Case and Cultivation Effect}

\subsection{Cultivation case}

Establishing an effective training model for exhibition professionals requires joint efforts from the government, industry, universities, and students. Based on path-goal theory, the present study proposes the implementation path of applied undergraduate exhibition professionals at the level of school, industry, government, and students, as shown in Figure 2.

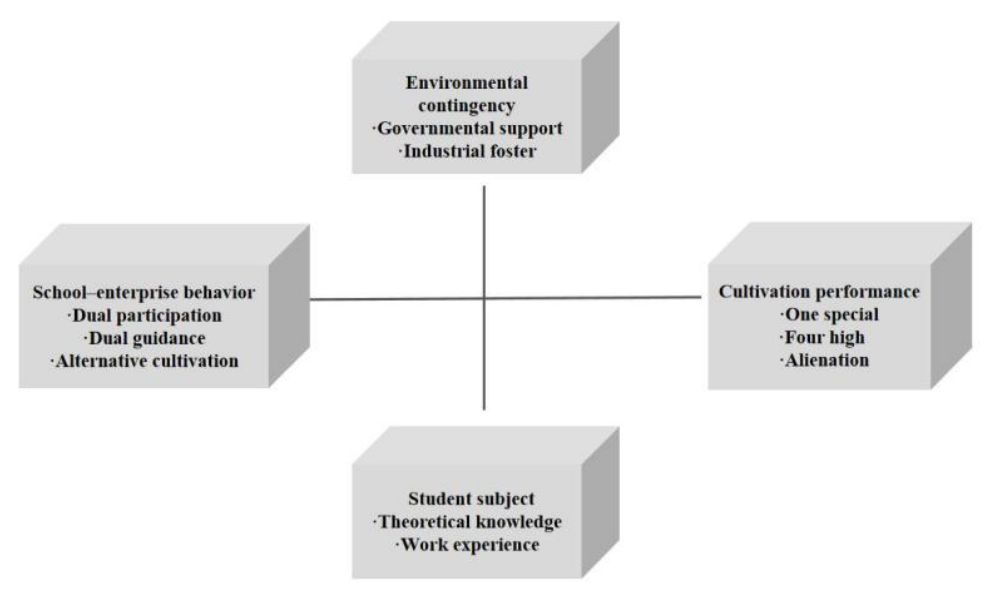

Fig. 2. Work-oriented convention and exhibition professionals development path

At the school and enterprise level, considering various internal or external situational factors, determining the general and specific objectives of exhibition professionals as a direction of efforts, and guiding the development of work-oriented undergraduates, that is, the choice of the critical path, are necessary. The student subject actively communicates with the school and enterprise during the implementation of the critical path and learns theoretical knowledge while accumulating work experience. The aim is to achieve professional skills and a high proportion of the employment rate in the industry, industry retention rate, and industry development rate [33]. Teaching students in accordance with their aptitude and achieving the "one special", "four high" and "alienation" goals of the study and employment, the choice of the critical path for professionals training should not be static. Various adjustments of environmental uncertainty and specific targets are the driving force and direction of its change. The scientific coordination of the environmental contingency factors of government support and industrial inclusion will reduce the lagging impact of environmental uncertainty and enhance the value of education. 


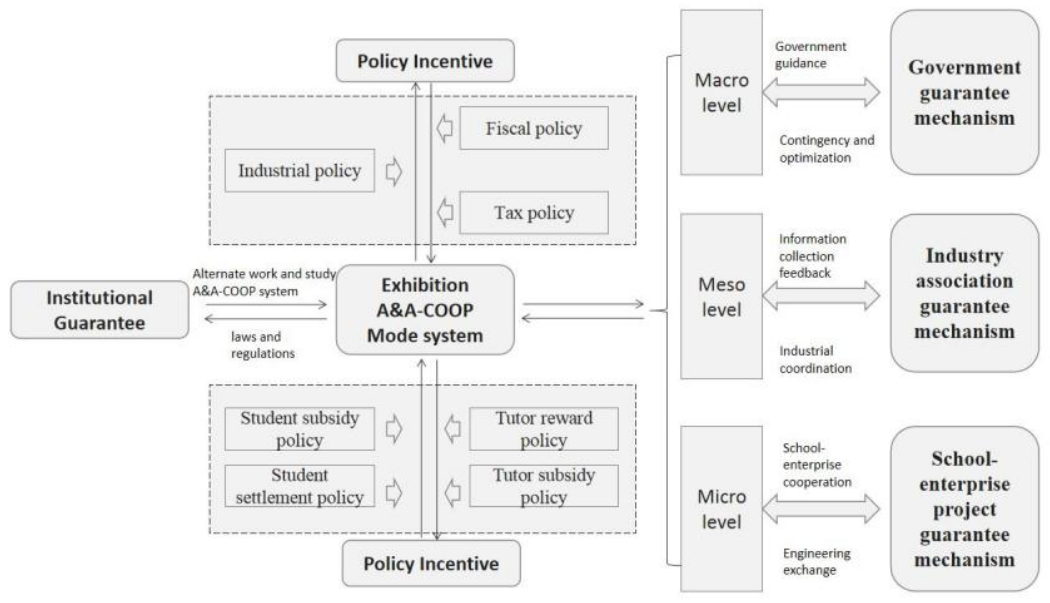

Fig. 3. Incentive and guarantee mechanism of the A\&A-COOP model system

Through the analysis above, the work-oriented undergraduate convention and exhibition professional school-enterprise "dual-element" education model will be based on relevant laws and regulations. Such model is possible through the government's macro-level guidance arrangement guarantee mechanism [34] and industry associations at the meso-level to collect feedback information. Figure 3 shows that the guarantee mechanism and the micro-level school-enterprise cooperation and cooperation of the alternate training project guarantee mechanism can be implemented in the work-oriented undergraduate college education [35].

\subsection{Cultivation effect}

Combining the analysis of path-target theory, building a student-centered school, enterprise, government, and industry four-in-one system for the convention and exhibition of work-oriented education professionals training in China is necessary. Such a system aims to realize the school-enterprise dual-alternating professional training operation mode of the convention and exhibition work-oriented undergraduates. Students and educational resources and social information will gradually grow into highquality exhibition professionals that can be input into the convention and exhibition enterprises and the government. This objective can be achieved through the combination of the learning and application practice process of the school-enterprise dualelement training of the convention and exhibition work-oriented colleges. Furthermore, Figure 4 shows that these exhibition professionals regurgitate on the convention and exhibition work-oriented institutions through the investment of enterprises and the convention and exhibition industry. 


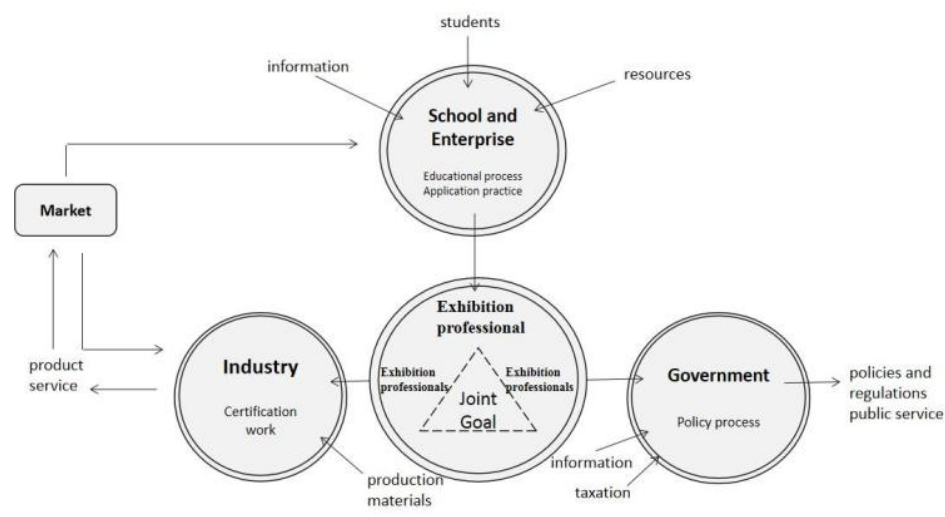

Fig. 4. Four-in-one flow elements around the convention and exhibition work-oriented undergraduate education

The cultivation and traditional training mode are implemented separately on Class A and Class B to study the theory and practice of convention and exhibition professionals and to verify the feasibility and effectiveness of the training model. The effect of undergraduate cultivation was evaluated, and Figure 5 shows the results of the survey.

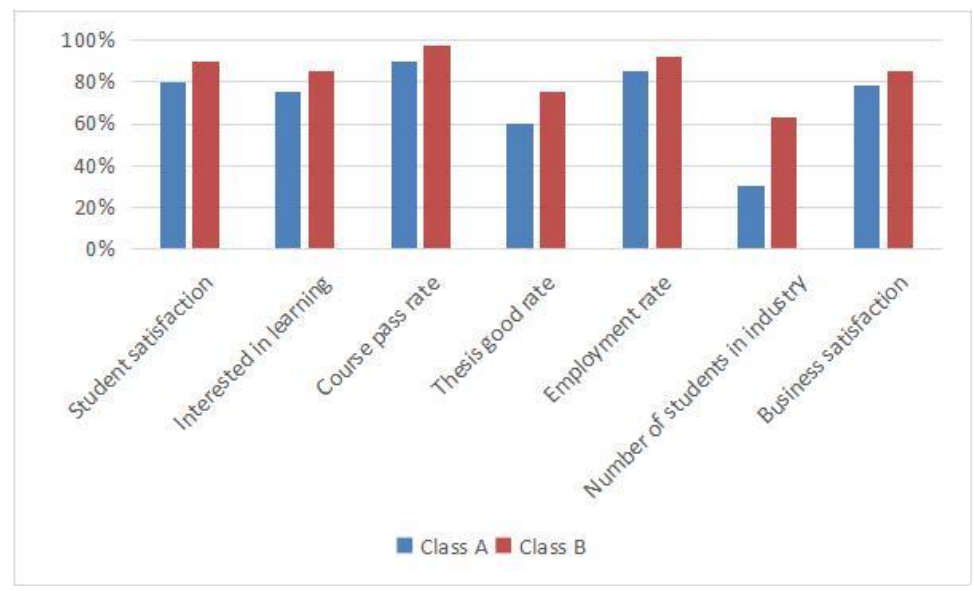

Fig. 5. Survey results

Figure 5 shows that Class B students perform better than Class A students. Through the feedback on the questionnaire, students and enterprises believe that under the cultivation mode described in this article, the training mode is intuitive and abundant, and students' interest in learning is improved to a certain extent. The rate of employment in the convention and exhibition industry of Class B students is much 
higher than that of Class A students especially in terms of the number of students who work in the convention and exhibition industry. This result indicates that students' enthusiasm for solving problems in the convention and exhibition industry remarkably improved, and students' practical ability is improved. The practice of alternating school and enterprise in the A\&A-COOP teaching mode achieved the goal of reforming the traditional exhibition professional teaching mode from the aspect of excellence rate of graduation thesis and employer satisfaction. Students who are trained in the cultivation mode described in this article can basically integrate professional and other forms of knowledge. In addition, they can basically meet the requirements of employers from graduates.

\section{Conclusion}

By comparing the traditional training and reformed cultivation mode, the new ideas of the A\&A-COOP model for the convention and exhibition work-oriented undergraduates can compensate for the lack of traditional teaching methods and improve the quality of teaching in the following ways.

- By using the reformed cultivation mode, the teaching process is no longer boring, and students develop a strong interest in learning and continue to study throughout the profession, thereby enhancing enthusiasm in independent learning. Students gain a strong grasp of knowledge points which achieves the purpose and requirements of teaching.

- During the academic semester, students can focus on learning basic and theoretical knowledge in school. During the semester of internship in enterprises, students integrate the necessary theoretical knowledge points into actual work process. In addition, students enhance the ability to analyze and solve actual exhibition problems. The ability to innovate improved remarkably, laying a good foundation for future work.

- By using the reformed cultivation mode, with the improving overall quality of students, the use of this training mode can meet the urgent needs of employers for convention and exhibition work-oriented professionals.

Therefore, this reform of the cultivation model for convention and exhibition professionals is successful, thereby providing a reference for the reform of convention and exhibition education, professional training system, and model construction.

\section{Acknowledgement}

This work was supported by the Huaqiao University Graduate Research Innovation Capacity Cultivation Project (No.17013121023). 


\section{$7 \quad$ References}

[1] Lan, X., Zhan, P.P., Pi, N.A. (2005). Exploring the establishment of the convention and exhibition education model in line with national conditions. Research in Educational Development, 21: 96-98. https://doi:10.3969/j.issn.1008-3855.2005.11.026

[2] Xiao, Y.N. (2005). Innovative Thinking on the Teaching Mode of China's Convention and Exhibition Specialty. Tourism Tribune, 1: 129-132. https://doi:10.3969/j.issn.1002-5006. $\underline{2006 . z 1.027}$

[3] Liu, S. (2014). The Integrated Path of Industry, Education and Research in Exhibition Education. Education Teaching Forum, 15: 177-179.

[4] Li, S.M., Chen, L.D. (2017). Quality Assurance of Higher Education in Canada: Motivation, System, Characteristics and Trends. Journal of Higher Education Management, 11(06): 109-116. https://doi:10.13316/j.cnki.jhem.20171027.016

[5] Lin, J., Wang, W. (2016). Analysis of Canadian Cooperative Education Project Certification System-Based on the Perspective of Stakeholders. Tsinghua Journal of Education, 37(05): 26-32+44. https://doi:10.14138/j.1001-4519.2016.05.002607

[6] Haddara, M., Skanes, H. (2007). A reflection on cooperative education: From experience to experiential learning. Asia-Pacific Journal of Cooperative Education, 8(1): 67-76.

[7] Beard, D.F. (1998). The status of internships/cooperative education experiences in accounting education . Journal of Accounting Education, 16(3-4): 507-516. https://doi.org/ $\underline{10.1016 / \mathrm{S} 0748-5751(98) 00021-9}$

[8] Parsons, C.K., Caylor, E. (2005). Simmons H S. Cooperative education work assignments: The role of organizational and individual factors in enhancing ABET competencies and coop workplace well-being. Journal of Engineering Education, 94(3): 309-318. https://doi.org/10.1002/j.2168-9830.2005.tb00855.x

[9] Yuan, G.L. (2015). Research universities should also carry out undergraduate vocational education - the enlightenment of the University of Waterloo. Modern University Education, 5: 71-76.

[10] Perry, M., Foley, P., Rumpf, P. (1996). Events management: An emerging challenge in Australian higher education. Festival Management and Event Tourism, 4(3-4): 85-93. https://doi.org/10.3727/106527096792195326

[11] McDonald, D., McDonald, T. (2000). Festival and event management: An experiential approach to curriculum design. Event Management, 6(1): 5-13.

[12] Hawkins, D.E., Goldblatt, J.J. (1995). Event management implications for tourism education. Tourism Recreation Research, 20(2): 42-45. https://doi.org/10.1080/02508281.1995. $\underline{11014747}$

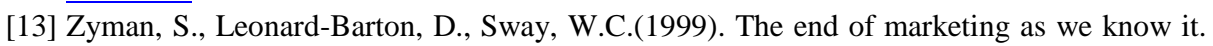
Harper Business, 45-49.

[14] Jin, H. (2003). The Status Quo of Conference and Exhibition Education in International Tourism Colleges and the Gap in China. Tourism Science, 1: 5-9. https://doi:10.16323/ j.cnki.lykx.2003.01.002

[15] Ma, Y. (2007). Reflections on the Internationalization and Localization of China's Exhibition Education. Proceedings of the 2007 Annual Conference of China Conference and Exhibition Economic Research Association, Beijing, China.

[16] Huang, Q.X. (2010). Research on the Construction of Tourism Cooperation Mechanism of Macao and Mainland Tourism Exhibition under CEPA.Journal of Qingdao Institute of Management Technology, 2(01): 58-61.

[17] Chen, L.M. (2010). Status Quo and Suggestions on the Development of University Conference and Exhibition Education. Journal of Zhongzhou University, 27(02): 19-21. 
[18] Wang, C.L. (2010). Study on the Mode of Project-Driven Professional professionalss Training-Taking the convention and exhibition Economy and Management Major of Shanghai Normal University as an Example. Tourism Science, 24(06): 84-92. https://doi:10.16323/j.cnki.lykx.2010.06.011

[19] Liu, D.K. (2006). Analysis of the Development Trend of China's Higher Conference and Exhibition Education. Journal of Beijing International Studies University, 5: 81-84.

[20] Wu, H.X. (2017). Discussion on the reform mode of practice teaching in exhibition industry-Taking Beijing Finance and Trade Vocational College self-organized exhibition as an example. China Market, 3: 237-238. https://doi:10.13939/j.cnki.zgsc.2017.03.237

[21] Xu, L.Q. (2017). Design Ideas and Implementation Path of Local Applied Undergraduate professionals Training Standards. Journal of Higher Education, 38(05): 81-85.

[22] Ye, F.F. (2017). The direction and path of the transformation of new undergraduate colleges to applied applications. Educational Research, 38(08): 72-77+90.

[23] Hong, W. (2015). Practice Research on COOP Education Model of University of Waterloo. Management Observer, 33: 112-113+117.

[24] Zha, Q., Zhu J., Wang, C.Y., Yang, Q.B. (2015). The Development of Balanced Education and Industry-University Cooperation Education in Canadian Universities. Research in Higher Education of Engineering, 5: 101-107.

[25] Wan, J.J., Geoffrey, W. (2017). The Cooperative Education Model of Canadian Universities and Its Enlightenment-Taking the University of Waterloo as an Example. Higher Education Exploration, 06: 82-85.

[26] Yin, H. (2011). The Enlightenment of Co-op Education Concept of Waterloo University to the Training Mode of Surveying and Mapping Engineering professionals. China University Teaching, 11: 93-94. https://doi:10.3969/j.issn.1005-0450.2011.11.031

[27] Waryszak, R.Z. (1997). Student perceptions of the cooperative education work environment in service industries. Progress in tourism and hospitality research, 3(3): 249-256. https://doi.org/10.1002/(SICI)1099-1603(199709)3:3<249::AID-PTH97>3.0.CO;2-E

[28] Ryder, K.G., Wilson, J.W. (1987). Cooperative Education in a New Era: Understanding and Strengthening the Links between College and the Workplace. Jossey-Bass Publishers, 34-36.

[29] Wang, Y.X., Cheng, B. (2017). From the Combination of Engineering and Learning to the Combination of Breeding: A New Idea of Training professionals in School-Enterprise Cooperation. Journal of Higher Education Management, 11(01): 111-115+124. https://doi:10. 13316/j.cnki.jhem.20161223.004

[30] Geng, C. (2018). Multi-common governance: the transformation of educational administrative methods. Journal of East China Normal University, 36(01): 35-41+161. https://doi: 10.16382/j.cnki.1000-5560.2018.01.005

[31] Van, G.G. (1997). Investigating the Educational Benefits of Cooperative Education: A Longitudinal Study. Journal of Cooperative Education, 32(2): 70-85.

[32] Dressler, S., Keeling, A.E. (2004). International handbook for cooperative education: An international perspective of the theory, research and practice of work-integrated learning. World Association for Cooperative Education, Boston, America.

[33] Zheng, X.M., Fan, X.L. (2010). On the concept and operation mode of professionals cultivation in the "four highs" of tourism majors. Human Geography, 25(06): 146-149. https://doi:10.13959/j.issn.1003-2398.2010.06.027

[34] Thomas, F.R., Qu, Q.J. (2016). Enterprises in Vocational Education and Training - Government Cooperation: Russia's "Double System" Education Experiment. Peking University Education Review, 14(03): 34-58+189-190. https://doi:10.19355/j.cnki.1671-9468.2016. $\underline{03.004}$ 
[35] Zhang, G.C., Hu, C.D. (2017). Analysis of Collaborative Innovation Models in Colleges and Universities from the Perspective of Fields. Educational Research: 38(05): 55-61.

\section{Authors}

Hui Zhang is currently the director the MICE economy and management Department and the associate professor and master tutor of College of Tourism, Huaqiao University, Quanzhou, China. His research interests focus on convention and exhibition education, business travel and exhibition economy management.

Rongteng Zhang is a Master student in College of Tourism, Huaqiao University, Quanzhou, China. She is interested in the co-operative education innovation, value co-creation and interaction in the field of exhibition and exhibition economy management.

Jie Yin, $\mathrm{PhD}$, is currently working in School of Tourism Management, Huaqiao University, China. His research interests focus on convention and exhibition education, exhibition economy and convention management.

Article submitted 2019-07-19. Resubmitted 2019-08-23. Final acceptance 2019-08-23. Final version published as submitted by the authors. 